\title{
Formulation and sensory evaluation of sorghum based weaning food fortified with soybean and unripe plantain flour
}

\author{
Nwakalor, Chizoba N.; Obi, Chioma D. \\ Department of Food Science and Technology, Federal Polytechnic Oko, Anambra State, Nigeria
}

Email address:

chizobanwakalor@ymail.com (Nwakalor C. N.)

\section{To cite this article:}

Nwakalor, Chizoba N.; Obi, Chioma D.. Formulation and Sensory Evaluation of Sorghum Based Weaning Food Fortified with Soybean and Unripe Plantain Flour. International Journal of Nutrition and Food Sciences. Vol. 3, No. 5, 2014, pp. 387-390.

doi: 10.11648/j.ijnfs.20140305.14

\begin{abstract}
Weaning food was formulated from different blends of sorghum, soybean and unripe plantain flour using a commercial weaning food (Golden morn) as control. The different percentages were 80:10:10, 60:20:20, 50:25:25. Sensory evaluation was done to determine which sample was most preferred in terms of taste, texture, flavour, colour and overall acceptability using 10 panelists on a nine point Hedonic scale. Analysis of variance was also done to ascertain which sample was significantly different from the control. The results showed that the 80:10:10 blend was preferred to all the parameters while the commercial weaning food was the least preferred.
\end{abstract}

Keywords: Weaning Food, Formulation, Sensory Evaluation, Soybean Flour and Unripe Plantain Flour

\section{Introduction}

Weaning is the process of gradually introducing a mammal infant to what will be its adult diet and withdrawing the supply of its mother's milk. Weaning foods are processed food given to babies from the age of four month and above to supplement breast milk. Since weaning foods are meant to supplement breast milk, it is necessary that they perform the same function as breast milk by supplying sufficient calories and protein for the growing child. Weaning food should contain vitamins and minerals present in the milk while providing additional calories. Formulated weaning food must be soft, acceptable and must contain the essential nutrients in the correct proportion to supply the babies need for growth and development. During the weaning period, semi-solid and the solid foods are introduced while breast feeding continues at lesser frequency. According to Mensah et al.,(1995), weaning food should be the same staple foods for adults, but made in smooth nourishing, appetizing and acceptable consistency suitable for baby. It is important that infant meals should contain adequate quantity of body building food attractively prepared and served in small quantities.
In most parts of Africa, the traditional weaning food which supplements breast feeding are gruels, watery suspension of cooled corn, sorghum and other available cereals. Such gruels serve the function of providing extra energy to body that is still fully breastfed.

Sorghum (Sorghum bicolor (L) Moench) also known as "Guinea-Corn" is one of the cereals that is most extensively grown in Nigeria that is adapted to wide range of ecological zone (Aba et al.2004).

Sorghum is the $5^{\text {th }}$ (fifth) most important cereal in total world production (Serna-Saldivar et al.1988). it is able to grow and produce in the warmer temperature and tropical regions of the world. Sorghum is the chief cereal grain consumed in Asia and Africa. About 700 million people are nourished by sorghum, since it constitutes a source of calories, protein and minerals. It is used to prepare foods for adults and children. The protein quality of sorghum grain is poor because of the low content of essential amino acids such as lysine, tryptophan and threonine (Badi et al. 1990). Sorghum, like the other cereals, is a good source of $\mathrm{B}$ vitamins such as thiamin, riboflavin, vitamin $\mathrm{B}_{6}$, biotin and niacin, but refining produces losses of all $\mathrm{B}$ vitamins (Hegedus et al.1985). The chief minerals present in sorghum grain are potassium grain are potassium and phosphorus while calcium is low (Khalil et al. 1984). 
Sorghum ( Sorghum bicolor (L) Moench ) is considered as one of the most important food crops in the world, following wheat, rice, maize and barley (FAO, 2006). Sorghum provides the staple food of a large population in Africa, India and the semi-arid parts of the tropics. It is commonly consumed by the poor masses of many countries and it forms a major source of proteins and calories in the diet of large segments of the population of India and Africa. Processed sorghum seeds or flour were found to be important sources of calories and proteins to vast majority of populations as well as for poultry and livestock (FAO,2006). Sorghum acts as a principal source of energy, proteins, vitamins and minerals for millions of the poorest people living in Africa, Asia and semi-arid tropics worldwide.

Sorghum is used for flours, porridges and side dishes, specialty foods such as popped grain and also for the production of alcoholic beverages. In Southern Africa and in Nigeria, sorghum is used to produce beer, including the local version of Guinness. Sorghum grain is used primarily as a maize substitute for livestock feed because their nutritional values are very similar. In arid, less developed regions of the world, sorghum is an important food crop especially for subsistence farmers. In recent years, sorghum has been used as a substitute for other grain in gluten free beer.

Soybeans have a rich nutrient content. Apart from being an excellent source of protein, it also contains all the essential fatty acids, calcium, magnesium, lecithin, riboflavin, thiamin, fiber, folic acid and iron.

Unripe plantain is rich in iron, potassium, B-complex vitamins and magnesium(Enwere, 1998, Ihekoronye and Ngoddy, 1985). It is also rich in dietary fiber and its consumption helps to cure anemia. Soybeans have a rich nutrient content. Apart from being an excellent source of proteins, it also contains all essential fatty acids, calcium, magnesium, lecithin, riboflavin, thiamin, fiber, folic acid and iron. Soy products act as perfect replacement for meat

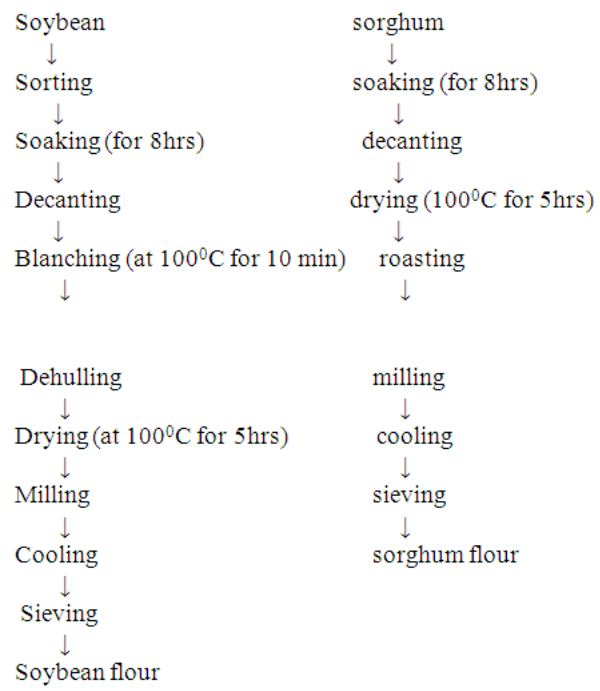

and dairy product specifically for the vegetarians while sorghum contains mainly carbohydrate of which starch and dietary fibers are the main components.

It is based on this background that it is imperative to produce sorghum based weaning food fortified with soybean and unripe plantain and also to ascertain the acceptability of the product using sensory evaluation.

\section{Materials and Methods}

The unripe plantain, sorghum and soybeans were purchased from Eke market, Ekwulobia, Anambra State.

\subsection{Method of Producing Unripe Plantain Flour}

The unripe plantain were cleaned, peeled, cut and blanched in hot water at $100^{\circ} \mathrm{C}$ for $10 \mathrm{~min}$ and dried in a cabinet dryer at $100^{\circ} \mathrm{C}$ for $5 \mathrm{hrs}$. It was later milled and sieved to get the flour.

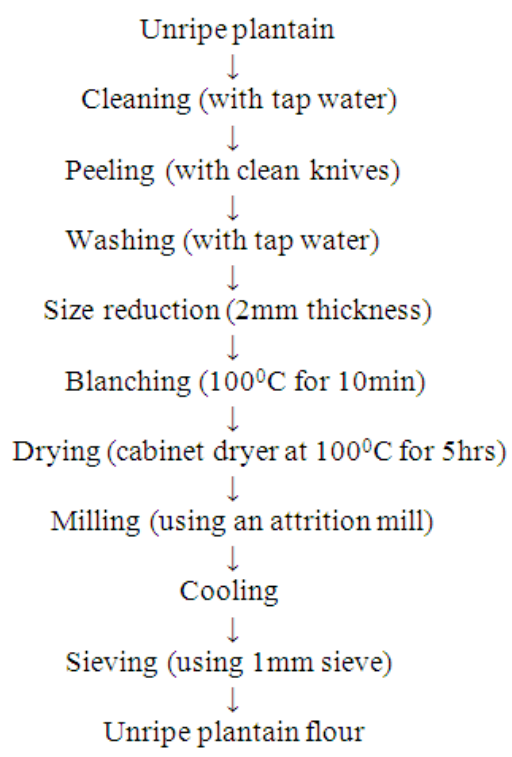

Fig 1. Unripe plantain flour production

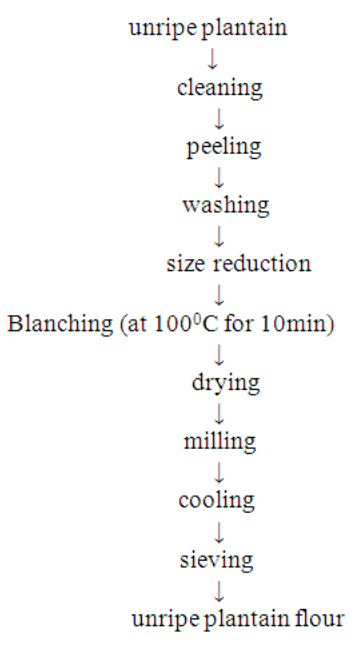

Fig 2. Flow chart for the preparation of the weaning food 


\subsection{Formulation of the Weaning Food}

Different percentages of roasted sorghum, unripe plantain and soybean flour were mixed in the following order.

Table 1. Formulation of the weaning food

\begin{tabular}{llll}
\hline Sample & sorghum flour & soybean flour & unripe plantain flour \\
\hline A & $80 \%(400 \mathrm{~g})$ & $10 \%(50 \mathrm{~g})$ & $10 \%(50 \mathrm{~g})$ \\
B & $60 \%(300 \mathrm{~g})$ & $20 \%(100 \mathrm{~g})$ & $20 \%(100 \mathrm{~g})$ \\
C & $50 \%(250 \mathrm{~g})$ & $25 \%(125 \mathrm{~g})$ & $25 \%(125 \mathrm{~g})$ \\
\hline
\end{tabular}

\subsection{Reconstitution of Weaning Food}

Each of the formula were poured in a bowl and dissolved with pure water, the formula was taken, transferred into little boiling water $\left(100^{\circ} \mathrm{C}\right)$ in a pot and was stirred for 1 minute to get a fine food, milk and sugar was then added to taste and stirred to a smooth consistency.

\section{Results and Discussion}

Results from sensory evaluation of sorghum based weaning food fortified with soybean and unripe plantain flours are shown in Table 2.

Table 2. Result of the Sensory Evaluation

\begin{tabular}{lllllll}
\hline Parameter & A & B & C & D & F cal. & F tab. \\
\hline Taste & $8.20^{\mathrm{a}} \pm 2.8$ & $8.00^{\mathrm{a}} \pm 2.4$ & $6.00^{\mathrm{b}} \pm 2.2$ & $5.40^{\mathrm{c}} \pm 1.8$ & 4.78 & 2.96 \\
Texture & $7.40^{\mathrm{a}} \pm 4.6$ & $7.20^{\mathrm{a}} \pm 2.6$ & $4.8^{\mathrm{b}} \pm 1.6$ & $2.80^{\mathrm{c}} \pm 0.6$ & 4.78 & 1.25 \\
Colour & $7.20^{\mathrm{a}} \pm 2.2$ & $6.60^{\mathrm{b}} \pm 1.6$ & $6.00^{\mathrm{b}} \pm 1.4$ & $5.00^{\mathrm{c}} \pm 1.2$ & 1.37 & 1.29 \\
Flavour & $8.40^{\mathrm{a}} \pm 2.8$ & $7.60^{\mathrm{b}} \pm 2.4$ & $6.20^{\mathrm{c}} \pm 2.2$ & $5.60^{\mathrm{d}} \pm 1.8$ & 10.4 & 4.60 \\
General Acceptability & $8.20^{\mathrm{a}} \pm 2.6$ & $8.40^{\mathrm{a}} \pm 1.8$ & $6.60^{\mathrm{b}} \pm 1.6$ & $5.60^{\mathrm{c}} \pm 1.2$ & 4.10 & 2.96 \\
\hline
\end{tabular}

\section{Discussion}

The mean scores of the sensory evaluation based on the sensory attributes taste, texture, colour, flavour and general acceptability. Sample A which has the ratio of $400 \mathrm{~g}$ sorghum, $50 \mathrm{~g}$ soybean and $50 \mathrm{~g}$ of unripe plantain has the highest mean score and general acceptability in the sensory attributes such as taste, texture, colour, flavour and general acceptability. This was followed by sample $\mathrm{C}$ with formulating ratio of $250 \mathrm{~g}$ of sorghum, $125 \mathrm{~g}$ of soybean and $125 \mathrm{~g}$ of unripe plantain flour while the control sample D which is the commercial golden morn was rated the least acceptable in that order. The analysis of variance also shows that sample A had the highest L.S.D. value while sample D (Golden Morn) had the least LSD values which is a further proof that sample A $(80: 10: 10)$ was more preferred than other samples while sample D (Golden Morn) was least preferred.

\section{Conclusion and Recommendation}

The result of this study shows that a highly nutritious weaning food can be prepared from cheap and locally available raw materials like sorghum, unripe plantain and soybean. This is because sorghum contains mainly carbohydrate which provides weaning child with lots of energy. However, sorghum like other cereals lack lysine and other sulphur containing amino acid but contains methionine and threonine while soybean ( a legume) which contains lysine as well as other sulphur containing amino acid, lack methionine and threonine hence the need to combine the two in this research work so as to get a more nutritious weaning food. Soybean an oil seed also contain fats which provide the infant with energy and warmth.
Sorghum is also rich in minerals such as calcium (for strong bones and teeth) for growing child, phosphorus, magnesium, iron and potassium which are essential for growth. Unripe plantain is also rich in energy as well as iron to help prevent anemia in a growing child. It is therefore important that weaning food formulated with sorghum, soybean and unripe plantain flours should be fed to weaned children to reduce the effect of stoppage breast feeding. This is very essential to reduce malnutrition in a developing country like Nigeria.

\subsection{Recommendation}

It is highly recommended that weaning baby food producing industries should commercial weaning food with sorghum, soybean and unripe plantain flours. Most especially, nursing mothers and all mothers should locally and hygienically prepare and introduce sorghum based weaning food fortified soybean and unripe plantain to reduce malnutrition in their weaned children since it is more nutritious and can be prepared with readily available and cheap locally sourced raw materials.

Hence, mothers and care givers should be properly educated on how to prepare such formula or blends. This is because average family in this country can hardly afford most weaning foods due to their exorbitant prices.

\section{References}

[1] Aba, D.A., Idem, N.U.A., Marley, P.S. and Maigida, D.N. (2004):Sorghum. Idem, N.U.A. and Sowemimo, F.A.(eds.) Cereals crops of Nigeria: principles of production and utilization. Ade Commerical press, Zaria. Pp. 38-78.

[2] Enwere, N.J.(1998). Foods of Plant Origin. Afro-Orbis publishers Ltd., Nigeria. P.24. 
[3] Mensah P, Ndiokwelu CI, Uwaegbute A, Ablordey A, van Boxtel AM, Brinkman C, Nout MJ,and Ngoddy PO.(1995). Feeding of lactic acid-fermented high nutrient density weaning formula in pediatrics settings in Ghana and Nigeria: acceptance by mother and infant and performance during recovery from acute diarrhea. Int $J$ Food Sci Nutr. 46(4):353-362.

[4] Ihekoronye, A.I and Ngoddy, P.O. (1985). Integrated Food Science and Technology for the Tropics. Macmillan Publishers, London. Pp 236-253.

[5] Badi,S., Pedersen, B., Monowar, L. and Eggum, B.O.(1990). The nutritive value of new and traditional sorghum and millet foods from Sudan. Plants Foods Hum., 40:5-19.
[6] Hegedus, M., Pedersen, B. and Eggum, B.O.(1985). The influence of milling on the nutritive value of flour from cereal grains: vitamins and tryptophan. Qual plant Plant foods Hum., Nutr. 35:175-180.

[7] FAO (2006). Official Agricultural Statistics $18^{\text {th }}$ edition, Food and Agricultural organization, Canada. Pp 1002-1004.

[8] Serna-saldivar, S.O., Telles-Giron, A. and Rooney, L.W. (1988). Production of tortilla chips from sorghum and maize. J.Cereal Sci.8: 275-284. 